\title{
Studies on the Transfer of Heavy Metals between Sedimentary Phases with a Multi-Chamber Device: Combined Effects of Salinity and Redox Variation*
}

\author{
ULRICH FÖRSTNER, WOLFGANG AHLF and WOLFGANG CALMANO \\ Section of Environmental Science and Technology, Technical University of Hamburg-Harburg, \\ Eißendorferstr. 40, D-2100 Hamburg (F.R.G.)
}

(Received October 25, 1988; revision accepted April 18, 1989)

\begin{abstract}
Förstner, U., Ahlf, W. and Calmano, W., 1989. Studies on the transfer of heavy metals between sedimentary phases with a multi-chamber device: combined effects of salinity and redox variation. Mar. Chem., 28: 145-158.
\end{abstract}

Mobilization and transfer of heavy metals to major sediment components after changes of typical estuarine conditions (salinity, redox potential/pH) have been studied in a newly developed experimental device, consisting of a central chamber connected with six external chambers and separated by membranes of $0.45-\mu \mathrm{m}$ pore diameter. Algal cell walls (Scenedesmus quadricauda), bentonite, $\mathrm{Al}$-oxide, $\mathrm{Mn}$-oxide, quartz powder and goethite were used as model sediment components. Significant metal enrichment was found on algal cell walls, and on freshly precipitated iron hydroxide. Oxidation of anoxic mud from Hamburg harbour causes lowering of $\mathrm{pH}$ and remobilization of cadmium and zinc. The experiments on the effect of seawater on sediment components and dredged mud indicate the dominant role of organic substrates in the binding of metals such as cadmium and copper, suggesting that even at relatively small percentages of organic substrates these materials are primarily involved in metabolic processes and thus may constitute the major carriers by which metals are transferred within the food chain. These results demonstrate that it is particularly problematic to disperse waste materials in ecologically productive, high-energy environments such as estuaries.

\section{INTRODUCTION}

There are many problems with polluted sediments in estuaries and coastal marine areas. Particular difficulties are connected with dredged materials which have to be removed from shipping channels and harbours. In river mouths on the southern coast of the North Sea, for example, $\sim 20$ million $\mathrm{m}^{3}$ have to be

\footnotetext{
*Presented at the 10th International Symposium "Chemistry of the Mediterranean", May 1988, Primošten, Yugoslavia.
} 
dredged from the Rhine/Meuse (Rotterdam Harbour) and 10 million $\mathrm{m}^{3}$ from the rivers Scheldt (Antwerp), Weser (Bremen) and Elbe (Hamburg)

Problems not only arise from those masses which are removed from rivers and have to be deposited on land. In addition, for those materials that are redeposited within the water body or resuspended by natural processes, adverse effects on related biota are to be expected. All these considerations led to the question how sediment composition is related to water quality and how its impact on aquatic ecosystems can be predicted. Several approaches to establish sediment quality are now being discussed (Battelle, Washington Operations, 1985 ), which include sediment enrichment factors, pore water com position, and equilibrium considerations. Other approaches include desorption procedures, both for short-term effects (conditions in the water phase: salinity, $\mathrm{pH}$, etc.) and long-term prognosis (e.g. sequential extraction procedures).

With respect to the modelling of metal partitioning between dissolved and particulate phases in a natural system, e.g. for estuarine sediments, the following requirements have been listed by Luoma and Davies (1983):

(1) determination of binding intensities and capacities for important sediment components;

(2) determination of relative abundance of these components;

(3) assessment of the effect of particle coatings and multicomponent aggregation on binding capacity of each substrate;

(4) consideration of the effect of major competitors $\left(\mathrm{Ca}^{2+}, \mathrm{Mg}^{2+}, \mathrm{Na}^{+}, \mathrm{Cl}^{-}\right)$;

(5) evaluation of kinetics of metal redistribution among sediment components.

It seems that models are still restricted, for various reasons:

(1) adsorption characteristics are related not only to the system conditions (i.e. solid types, concentrations and adsorbing species), but also to changes in the net system surface properties resulting from particle/particle interactions such as coagulation (Honeyman, 1984);

(2) influences of organic ligands in the aqueous phase can rarely be predicted as yet;

(3) effects of competition between various sorption sites and reaction kinetics of the individual constituents cannot be evaluated in a mixture of sedimentary components.

At present, experimental studies on the dissolved/solid interactions in such complex systems seem to be more promising. We are using a six-chamber device, in which the individual components are separated by membranes which still permit phase interactions via solute transport of the elements. In this way, exchange reactions and biological uptake can be studied for individual phases under the influence of $\mathrm{pH}$, redox, ionic strength, solid and solute concentration, and other parameters. 


\section{METHODS AND SELECTION OF PARAMETERS}

\section{The multi-chamber device}

The laboratory system used in these studies was developed from experience on sediment/algae interactions with a modified two-chambered device (Ahlf, 1985; Ahlf et al., 1986), which was described by DePinto (1982). The system is made of a central chamber connected with six external chambers and separated by membranes of $0.45-\mu \mathrm{m}$ pore diameter (Fig. 1 ). The use of other membranes is possible. The volume of the central chamber is $\sim 4$ and each of the external chambers has $250-\mathrm{ml}$ capacity. Either a solution or a suspension can be inserted into the central chamber; in each external chamber the single solid components are kept in suspension by magnetic stirring. Redox, $\mathrm{pH}$ and other parameters may be controlled and adjusted in each chamber.

Supplementary experiments on the transfer of selected elements from sediments to biota were performed in a two-chamber system (see above), also separated by a $0.45-\mu \mathrm{m}$ membrane. One vessel contained $0.5 \%$ (wt./vol.) suspended solids and the other vessel $2 \times 10^{6}$ cells $\mathrm{ml}^{-1}$ of Stichococcus. This alga was adapted to varying external salinity.

\section{Selection of parameters}

The present studies are performed in the framework of a multidisciplinary project on the interactions between abiotic and biotic processes in the Elbe River estuary (Schoer et al., 1989). Figure 2 is a schematic diagram of the variations of typical parameters in a longitudinal section of the tidal Elbe River. The position of the salinity gradient and dependent parameters, such as tur-
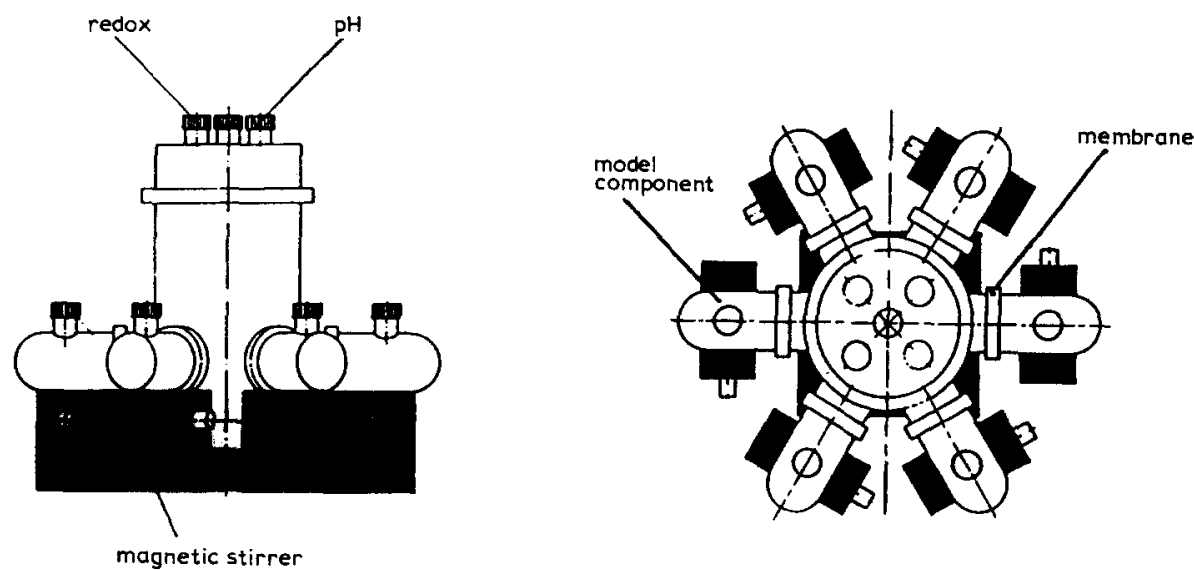

Fig. 1. Schematic view of the multi-chamber device. 

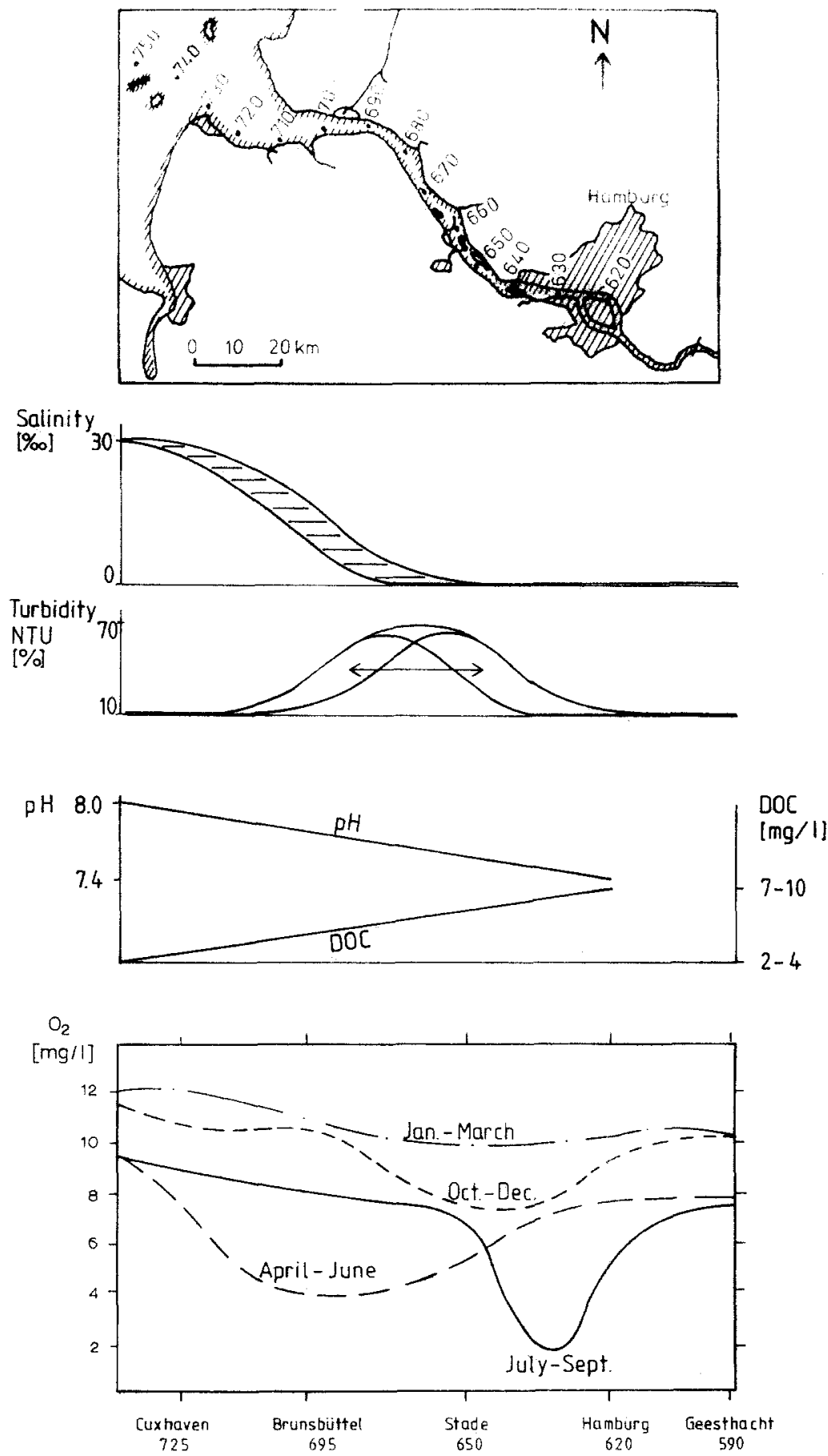

Fig. 2. Schematic diagram of the variations of typical parameters in a longitudinal section of the tidal Elbe River. (Oxygen content: Tent (1987), after data from ARGE Elbe reports (1978-1985).) 
bidity, are predominantly determined by water discharge; $\mathrm{pH}$ varies between 7.4 and 8.1; and dissolved organic carbon (DOC) concentrations vary between 7-10 and 2-4 $\mathrm{mg} \mathrm{l}^{-1}$. Significant changes can be observed for oxygen concentrations (Fig. 2, below); during the summer months a typical 'oxygen hole' occurs downstream from the city of Hamburg, as a result of enhanced biological degradation of organic matter.

The distinct decrease of metal concentrations in particulate matter within estuaries is mostly a result of the mixing of more contaminated river inputs with relatively clean marine sediments; however, release of trace metals (mainly cadmium) from suspended particulates and sediments has been reported from several estuaries (Salomons and Förstner, 1984), including the Elbe estuary (Ahlf, 1983; Calmano et al., 1985; Mart et al., 1985). Remobilization has been explained by complexing reactions with chloride and/or ligands from the decomposing organic matter in the water. In this way, uptake by the suspended matter, or precipitation on it, may be inhibited. In addition, it has been suggested by Millward and Moore (1982) that the major cations, magnesium and calcium, are probably co-adsorbed. Competition between these species for adsorption sites increases with increasing salinity.

Oxidative remobilization of cadmium and other heavy metals has been studied in a tidal freshwater flat in the upper Elbe estuary near Hamburg (Kersten and Kerner, 1985). This mudflat is affected by diurnal tidal water fluctuations in the range of $3 \mathrm{~m}$. Examination of sediment cores taken at this site showed a distinct redox potential pattern (Fig. 3 ) and heavy metal fractionation profiles: although in the anoxic zone $\sim 60-80 \%$ of Cd occurs in the oxidizable fraction (mainly sulphide), high percentages of $\mathrm{Na}$-acetate extractable cad-

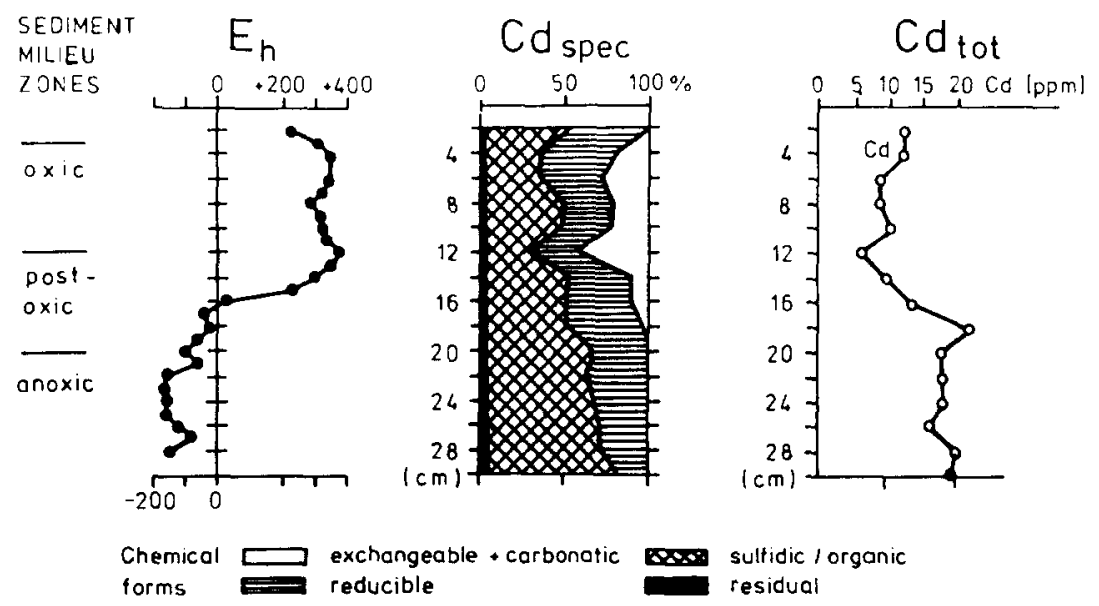

Fig. 3. Heuckenlock intertidal flat in the Elbe near Hamburg: sediment milieu zones/Eh conditions, chemical forms of cadmium and bulk cadmium distribution in a core profile (after Kersten and Kerner, 1985). 
mium are found in the oxic and post-oxic zones of the sediment cores. The higher amounts of labile cadmium forms are accompanied by a marked deple tion in the total metal content compared with that in the anoxic sediment zone. A comparison of the fractionation patterns and total contents of other diagenetically less mobile metal examples suggests that a significant proportion of cadmium is leached from the surface sediment by a process of 'oxidative pumping' by tidal water drainage in this high-energetic environment. This could result in migration of the remobilized metal into either the deeper anoxic zone, where it can precipitate again to contribute to the enhanced oxidizable sulphidic/organic fraction, or to the surface water, from where it can be exported to the outer estuary. It could, however, also contribute to bioavailable cadmium, as indicated by the enhanced macrophyte cadmium concentrations (Kersten and Kerner, 1985).

According to these findings, in the present experiments, emphasis was placed on variations in salinity and redox potential, and, in particular, on combinations of these parameters.

\section{Experiments}

In the first experimental series the effects of redox variations were studied. The following quantities of substrates were inserted into the outer chambers: $0.28 \mathrm{~g}$ algal cell walls, $1.28 \mathrm{~g}$ aluminium oxide, $1.19 \mathrm{~g}$ goethite, $0.14 \mathrm{~g}$ bentonite, and $10 \mathrm{~g}$ quartz powder. These quantities were each equivalent to a total cation exchange capacity of $127 \mathrm{~mol}(100 \mathrm{~g})^{-1}$. Nitrogen was bubbled through the suspension to keep the system anoxic. Redox potential and $\mathrm{pH}$ values were
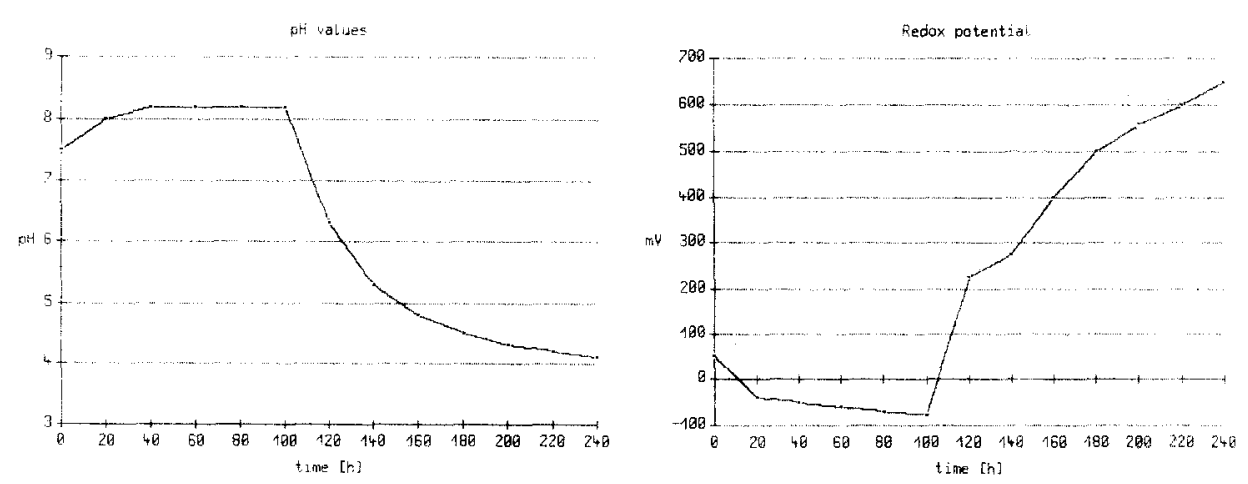

Fig. 4. pH and Eh development during the redox experiment. 
measured continuously. After $100 \mathrm{~h}$, solid samples and filtered water samples were collected from each chamber and analysed by atomic absorption spectroscopy. The sludge suspension in the central chamber was then aerated; after $240 \mathrm{~h}$, the dissolved and particulate metal concentrations were analysed again. Figure 4 shows the development of $\mathrm{pH}$ and redox during the experiments. There exists a clear interdependence between both parameters: during the anoxic run $\mathrm{pH}$ values in the sludge suspension remain at $\sim 8$ and redox potential at $\sim-50$ $\mathrm{mV}$. After aeration the redox potential increases from $-75 \mathrm{mV}$ to $\sim+650 \mathrm{mV}$ and the $\mathrm{pH}$ decreases from 8 to 4.2 .

In a second series of experiments the effect of salinity, i.e. disposal of anoxic dredged mud into seawater, was simulated. Quantities of model components were chosen in analogy to an average sediment composition: $0.5 \mathrm{~g}$ algal cell walls $(=5 \%), 3 \mathrm{~g}$ bentonite $(=30 \%), 0.2 \mathrm{~g}$ Mn-oxide $(=2 \%), 0.5 \mathrm{~g}$ goethite $(=5 \%)$, and $5 \mathrm{~g}$ quartz powder $(=50 \%)$. In the central chamber, $100 \mathrm{~g}$ of anoxic mud from Hamburg harbour was inserted; salts were added corresponding to the composition of seawater. After 3 weeks, solid samples and filtered water samples were collected from each chamber and analysed by atomic absorption spectroscopy.

\section{RESULTS AND DISCUSSION}

\section{Results}

Metal concentrations in solution and in solids of the first experimental series on the effect of redox variations are given in Fig. $5(\mathrm{a}-\mathrm{c})$. The bars represent the concentrations of copper, zinc and cadmium in the anoxic and oxic systems. In anoxic conditions metal concentrations were all relatively low. After oxidation of the sediment suspension all dissolved metal concentrations are distinctly increased, and the same effect can be observed for the model substrates. For copper (Fig. 5a), the distribution in the solids is dominated by cell wall adsorption; zinc (Fig. 5b) is mainly found in bentonite, which is also the major receiving phase for cadmium (Fig. 5c). The control chamber often exhibits higher concentrations of metals in solid matter; these are mainly precipitates or iron oxyhydrates. It can be concluded that at least part of the metal concentrations on other substrates are also affected by this mechanism.

During the second experimental series on the effects of seawater $\sim 16$ and $9 \%$, respectively, of total $\mathrm{Cd}$ and $\mathrm{Zn}$ in the dredged mud are remobilized and found in solution; the mobilized portion on $\mathrm{Cu}$ is $<1 \%$ of the respective element concentration in the mud sample. Algal cell walls are the most important sorption sites for $\mathrm{Cd}$ and $\mathrm{Cu}$ in this model system, although sorption takes place also on the other components. $\mathrm{Zn}$ is mainly sorbed on bentonite. This is in accordance with results of the previous experiment (Calmano et al., 1988a) where $\mathrm{Zn}$ was found strongly attached to this clay mineral in seawater. 

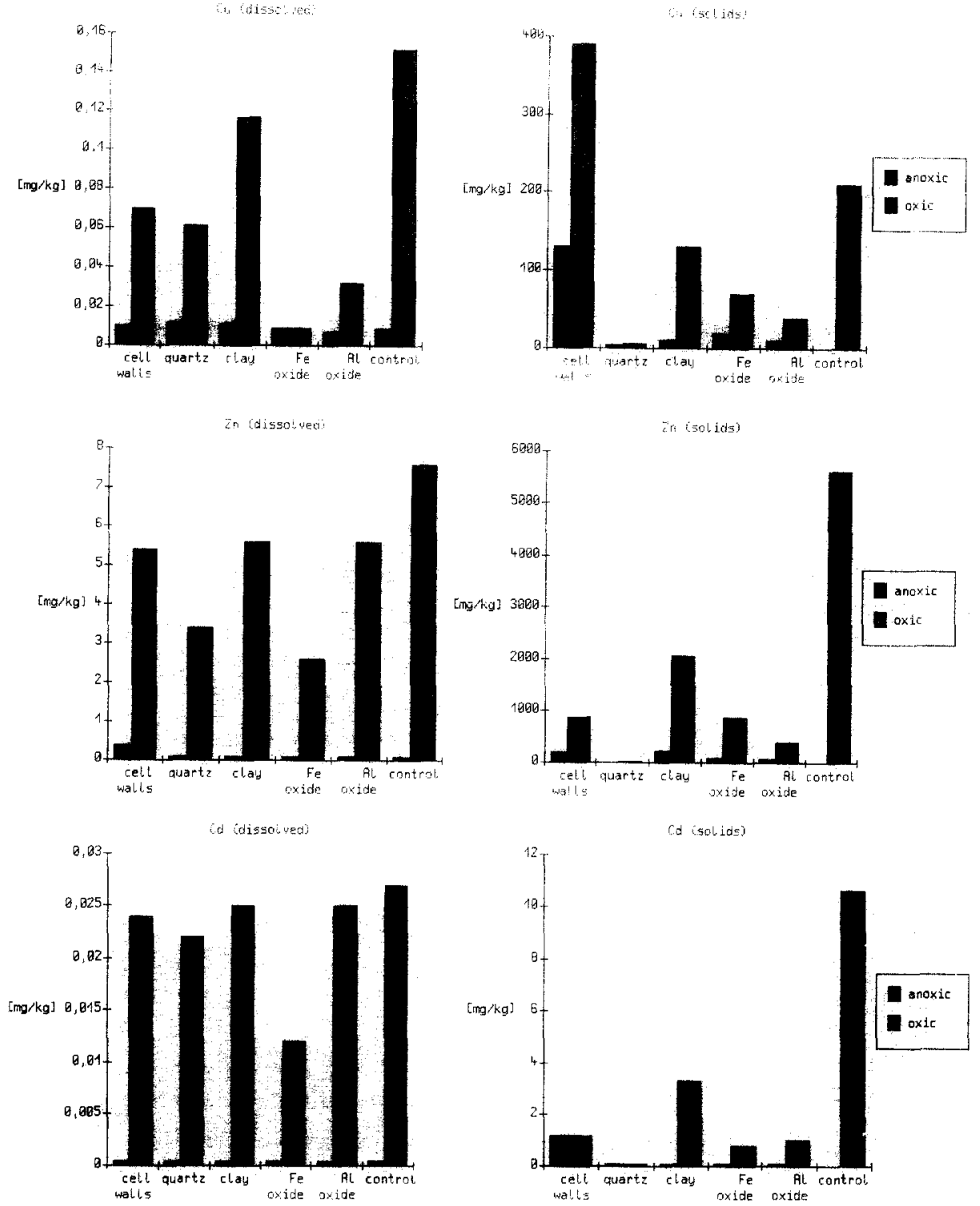

Fig. 5. Concentrations of (a) copper, (b) zinc and (c) cadmium in solutions and respective model substrates in the multi-chamber experiments at anoxic and oxic conditions.

\section{Discussion}

Apart from direct inputs of acidity, e.g. by acid precipitation, oxidation of anoxic sediments is the most efficient factor in mobilization of trace elements in the environment (Förstner, 1987). Under oxidizing conditions the controlling solids may change gradually from metallic sulphides to carbonates, oxy- 
hydroxides, oxides, or silicates, thus changing the solubility of the associated trace metals ( $\mathrm{Lu}$ and Chen, 1977). Experimental data of Gambrell et al. (1977) indicate that considerable metal release may occur as contaminated sediment is transported from a near-neutral $\mathrm{pH}$, reducing environment to a moderately acid, oxidizing environment. Element mobilization from porewater of contaminated sediment has been investigated by Darby et al. (1986) in a man-made estuarine marsh: when the expected concentrations of metals after hydraulic dredging, which were calculated from a ratio of porewater to river water of $\sim 1: 4$, were compared with the measurements at the exit pipe of the dredging device, characteristic mobilization of $\mathrm{Zn}, \mathrm{Cu}, \mathrm{Pb}$ and $\mathrm{Cd}$ (by a factor of six and more) was found.

Remobilization of trace metals from anoxic sediments is predominantly caused by microbial oxidation of pyrite and other iron sulphides (Singer and Stumm, 1970). There is a significant decrease of $\mathrm{pH}$ values in less buffered, low-carbonate dredged sludges - such as those from Hamburg harbour - after some time (months to several years) subsequent to land disposal. This can be explained by the activity of Thiobacillus thiooxidans and T. ferrooxidans in oxidizing sulphur and ferrous iron; with decrease in $\mathrm{pH}$, the process of metal dissolution from dredged sludge is enhanced. In a laboratory system, acidification with sulphurous acid to $\mathrm{pH} 4.0$ and subsequent bacterial leaching solubilized the following metal percentages from the dredged sediments of Hamburg harbour (Calmano et al., 1983): $\mathrm{Cd}$ and $\mathrm{Co}, 98 \% ; \mathrm{Mn}, 91 \% ; \mathrm{Cu}, 84 \% ; \mathrm{Ni}$, $66 \%$; $\mathrm{Cr}, 45 \% ; \mathrm{Fe}, 27 \%$; and $\mathrm{Pb}, 17 \%$. On the other hand, oxidation of wellbuffered anoxic sediments causes relatively low metal mobilization. Data from a multi-chamber experiment, in which $\mathrm{pH}$ values were kept constant at 7.5, indicate that concentrations of copper, cadmium, and zinc in solution, under both anoxic and oxic conditions, are very low and no significant transfer to the model sediment components could be observed, with the exception of copper and cadmium for algal cell walls, where an increased content was found under buffered oxic conditions (Calmano et al., 1988b).

Readsorption may occur for metal species whose strength of binding to model components exceeds their strength of binding to dredged material, but this occurs only if metals are released from the sediments are transferred to the model components via solution. It can be concluded from our experiments at low $\mathrm{pH}$ values that the binding strengths of the studied metals, in particular on bentonite and iron oxyhydrates (and additionally for copper on algal cell walls), are relatively strong.

With respect to the effect of salinity on the remobilization of metals from contaminated sediments, which is significant for $\mathrm{Cd}$ and $\mathrm{Zn}$ in the dredged mud from Hamburg harbour (16 and 9\%, respectively, of total metal content), it has been stressed by Prause et al. (1985) that simple cation exchange mechanisms obviously have no importance at least for cadmium, where maximum remobilization rates have been found after 2-4 weeks of intensive resuspension 
of test mud. Rather, it is suggested from batch tests, using temporal additions of antibiotics, that bacterial activity can stimulate cadmium remobilization by a complex web of substrate decomposition - including oxidation of sulphides - and potential ligand liberation or formation. Complexation with chloride and/or competition with alkaline earth ions is only the last step in this process, by partly inhibiting readsorption of metals such as cadmium onto suspended matter. In practice, these data of Prause et al. (1985) and earlier findings by Salomons (1980) emphasize the fact that the time-spans of typical release processes are much longer than the short-term fluctuations in estuarine properties, such as tidal advection and associated processes. A long particle residence time probably causes a stronger remobilization of the metal from the suspended matter and indicates that observations on the quantitative behaviour of cadmium as determined for one estuary cannot be extrapolated to other estuaries, as chemical and hydrodynamic processes may differ to a large extent (Kersten and Förstner, 1987).

For metals such as copper, the 'salinity increase' factor, in contrast to the well-defined effects of acidity, seems to be less important in the transfer both among individual sediment substrates and to aquatic biota. However, this is not true, as can be demonstrated from a mass balance for copper in Fig. 6: it is indicated that $\sim 1.3 \%$ of the inventory of copper of the sludge sample is released when treated with seawater. Only one-third stays in solution, equivalent to $\sim 40 \mathrm{~g} 1^{-1}$, and there is no significant difference in the conditions before salt addition. Two-thirds of the released copper is readsorbed at different affinities to the model substrates. Quartz contains only $3 \mathrm{ppm}$ of copper and bentonite clay contains $\sim 15 \mathrm{ppm}$, i.e. copper concentrations is these substrates are not significantly different from their natural contents. Slight en-

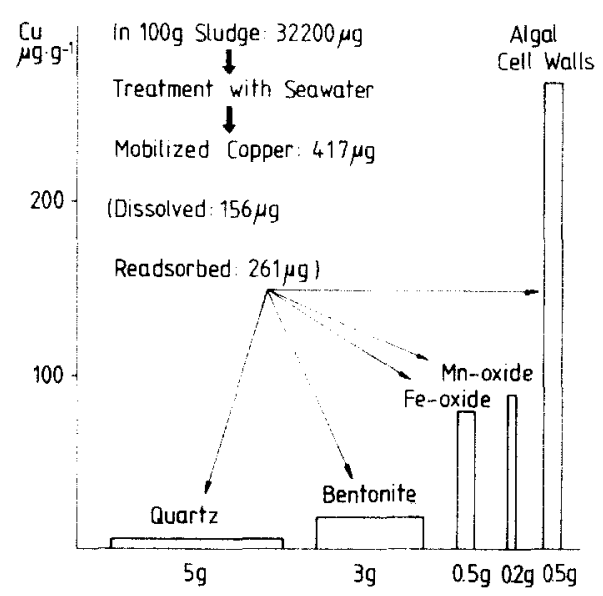

Fig. 6. Transfer of copper from anoxic harbour mud into different model substrates after treatment with artificial seawater. 
cd

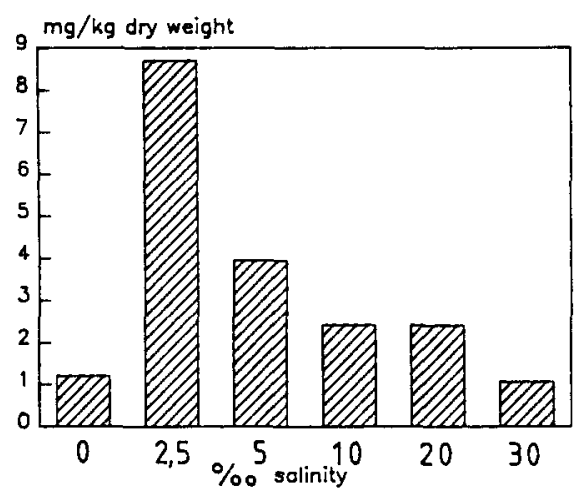

Cu

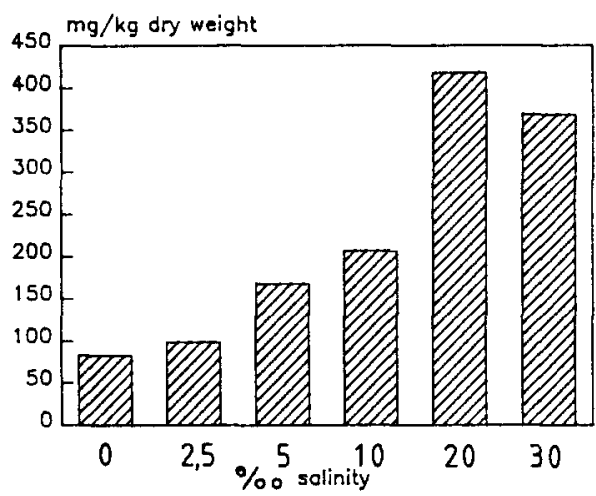

Fig. 7. Effect of salinity on metal contents in Stichococcus bacillaris grown for $96 \mathrm{~h}$ with resuspended sediment (Ahlf, 1987).

richment of copper is observed in the iron hydroxide ( $\sim 80 \mathrm{ppm})$ and manganese oxide $(100 \mathrm{ppm})$, whereas the cell walls - a minor component in the model sediment - have accumulated nearly $300 \mathrm{ppm}$ of copper.

The dominant role of organic substrates in the binding of metals such as $\mathrm{Cd}$ and $\mathrm{Cu}$ is of particular relevance for the transfer of these elements into biological systems. It can be expected that even at relatively small percentages of organic substrates these materials are primarily involved in metabolic processes and thus may constitute the major carriers by which metals are transferred within the food chain.

Here, however, quantitative information is lacking on the mechanisms and effects involving degradation products from such organic substrates as well as on the significance of biological processes in these laboratory systems. Initial experiments using test alga Stichococcus - which was adapted to varying salinities - in a two-chamber system (Ahlf, 1987) indicated that the accumulation on organic surfaces is mainly affected by complexation with chlorine and the competition with calcium and magnesium ions. Cadmium peaked at a salinity of $2.5 \%$, but was much reduced with increasing salinity (Fig. 7a); these data confirm the findings of Rebhuhn and Ben-Amotz (1984) that cadmium is less available for biological uptake in seawater owing to complexation with chlorides and other anions. The amount of copper sorbed by Stichococcus was lowest in freshwater, and increased with increasing salinity (Fig. 7b).

\section{CONCLUSIONS}

The multi-chamber device allows the investigation of heavy metal sorption/ desorption processes on typical sediment components with different surface binding intensities, which are competing for the metals in solution. Parameters 
that have been studied include salinity and redox $/ \mathrm{pH}$ variations, both of which are important factors controlling the interactions of dissolved and solid metal species in estuaries. Future experiments should focus on the influence of suspended matter concentrations and on the significance of organic and inorganic coatings on mineral substrates.

The strongest effects on metal mobility have been observed on oxidation of anoxic sediments. An important result is that the $\mathrm{pH}$ development and most subsequent effects strongly depend on the sludge composition. At low buffer capacities, oxidation of sulphides, which is mediated by bacteria, causes significant lowering of $\mathrm{pH}$ and enhanced transfer of trace metals into solution and to secondary substrates. When $\mathrm{pH}$ is kept neutral, metal transfer is generally low, except for copper and cadmium transfer to algal cell walls under oxic conditions.

In contrast to the well-defined effects of acidity, the 'salinity increase' factor seems to be less important in the transfer both among individual sediment substrates and to aquatic biota. However, the example of copper has shown that even at relatively small percentages of organic substrates these materials may constitute the major carriers by which metals are transferred within the food chain. Initial studies using a two-chamber algal test device indicate that uptake of individual elements by biota is typically affected by salinity. Further investigations will be undertaken to evaluate other factors in the metal transfer in estuarine ecosystems.

The data presented here demonstrate that it is particularly problematic to disperse waste materials in ecologically productive, high-energy environments such as estuaries. Resuspension of anoxic sediments may lead to remobilization and subsequent food chain enrichment of potentially toxic elements.

\section{REFERENCES}

Ahlf, W., 1983. The River Elbe: behaviour of $\mathrm{Cd}$ and $\mathrm{Zn}$ during estuarine mixing. Environ. Technol. Lett., 4: 405-410.

Ahlf, W., 1985. Verhalten sedimentgebundener Schwermetalle in einem Algentestsystem, charakterisiert durch Bioakkumulation und Toxizität. Vom Wasser, 65: 183-188.

Ahlf, W., 1987. Transfer of heavy metals from suspended sediments to the alga Stichococcus bacillaris in estuarine water medium. In: Spec. Conf. Coastal and Estuarine Pollution, Kyushu University, Oct. 19-21, 1987. IAWPRC, London, pp. 36-41.

Ahlf, W., Calmano, W. and Förstner, U., 1986. The effects of sediment-bound heavy metals on algae and importance of salinity. In: P.G. Sly (Editor), Sediments and Water Interactions. Springer-Verlag, New York, pp. 319-324.

Battelle Washington Operations, 1985. Sediment Quality Criteria Development Workshop, Nov. $28-30,1985,25 \mathrm{pp}$.

Calmano, W., Ahlf, W. and Förstner, U., 1983. Heavy metal removal from contaminated sludges with dissolved sulfur dioxide in combination with bacterial leaching. In: Proc. Int. Conf. Heavy Metals in the Environment, Heidelberg. CEP Consultants, Edinburgh, pp. 952-955. 
Calmano, W., Wellershaus, S. and Liebsch, H., 1985. The Weser estuary: a study on heavy metal behaviour under hydrographic and water quality conditions. Veröff. Inst. Meeresforsch. Bremerh., 20: 151-182.

Calmano, W., Ahlf, W., Baade, H. and Förstner, U., 1988a. Transfer of heavy metals from polluted sediments under changing environmental conditions. In: M. Astruc and J.N. Lester (Editors), Heavy Metals in the Hydrological Cycle. Proc. Int. Conf. Chemicals (Heavy Metals) in the Environment. Selper, London, pp. 501-506.

Calmano, W., Ahlf, W. and Förstner, U., 1988b. Study of metal sorption/desorption processes on competing sediment components with a multi-chamber device. Environ. Geol. Water Sci., 11: $77-84$.

Darby, D.A., Adams, D.D. and Nivens, W.T., 1986. Early sediment changes and element mobilization in a man-made estuarine marsh. In: P.G. Sly (Editor), Sediments and Water Interactions. Springer-Verlag, New York, pp. 343-351.

DePinto, J.V., 1982. An experimental apparatus for evaluating kinetics of available phosphorus release from aquatic particulates. Water Res., 16: 1065-1070.

Förstner, U., 1987. Changes in metal mobilities in aquatic and terrestrial cycles. In: J.W. Patterson and R. Passino (Editors), Metals Speciation, Separation and Recovery. Lewis, Chelsea, MI, pp. 3-26.

Gambrell, R.P., Khalid, R.A., Verloo, M.G. and Patrick, W.H., Jr., 1977. Transformations of heavy metals and plant nutrients in dredged sediments as affected by oxidation/reduction potential and $\mathrm{pH}$. II. Materials and methods/results and discussion. U.S. Army Corps of Engineers, Dredged Material Research Program, Rep. D-77-4, Vicksburg, MS, 309 pp.

Honeyman, B.D., 1984. Metal and metalloid adsorption at the oxide/water interface in systems containing mixtures of adsorbents. Ph. D. Thesis, Stanford University, Stanford, CA.

Kersten, M. and Förstner, U., 1987. Cadmium associations in freshwater and marine sediment. In: J.O. Nriagu and J.B. Sprague (Editors), Cadmium in the Aquatic Environment. Wiley, New York, pp. 51-88.

Kersten, M. and Kerner, M., 1985. Transformations of heavy metals and plant nutrients in a tidal freshwater flat sediment of the Elbe estuary as affected by $\mathrm{E}_{\mathrm{h}}$ and tidal cycle. In: Proc. Int. Conf. Heavy Metals in the Environment, Athens, Vol. 1. CEP Consultants, Edinburgh, pp. 533-535.

Lu, C.S.J. and Chen, K.Y., 1977. Migration of trace metals in interfaces of seawater and polluted surficial sediments. Environ. Sci. Technol., 11: 174-182.

Luoma, S.N. and Davis, J.A., 1983. Requirements for modelling trace metal partitioning in oxidized estuarine sediments. Mar. Chem., 12: 159-181.

Mart, L., Nürnberg, H.W. and Rützel, H., 1985. Levels of heavy metals in the tital Elbe and its estuary and the heavy metal input into the sea. Sci. Total Environ., 44: 35-49.

Millward, G.E. and Moore, R.M., 1982. The adsorption of $\mathrm{Cu}, \mathrm{Mn}$ and $\mathrm{Zn}$ by iron oxyhydrate in model estuarine solutions. Water Res., 16: 981-985.

Prause, B., Rehm, E. and Schulz-Baldes, M., 1985. The remobilization of $\mathrm{Pb}$ and $\mathrm{Cd}$ from contaminated dredge spoil after dumping in the marine environment. Environ. Technol. Lett., 6: 261-266.

Rebhuhn, S. and Ben-Amotz, A., 1984. The distribution of cadmium between the marine alga Chlorella stigmatophora and sea water medium. Water Res., 18: 173-178.

Salomons, W., 1980. Adsorption processes and hydrodynamic conditions in estuaries. Environ. Technol. Lett., 1: 356-365.

Salomons, W. and Förstner, U., 1984. Metals in the Hydrocycle. Springer-Verlag, Berlin, 349 pp.

Schoer, J., Förstner, U. and Knauth, K.-D., 1989. Heavy metals in the Elbe estuary - historical conceptions, actual research and future perspectives. Int. Symp. Fate and Effects of Toxic Chemical in Large Rivers and Estuaries, Quebec, Oct. 10-14, 1988. Sci. Total Environ., in press. 
Singer, P.C. and Stumm, W., 1970. Acid mine drainage: the rate determining step. Science, 167: $1121-1123$.

Tent, L., 1987. Contaminated sediments in the Elbe estuary: ecological and economic problem for the Port of Hamburg. In: R.L. Thomas, R. Evans, A. Hamilton, M. Munawar, T. Reynold. son and H. Sadar (Editors), Ecological Effects of In Situ Sediment Contaminants. Hydro biologia, 149: 189-199. 